\title{
14. The Electoral Geography of the 2013 Election: Voting patterns in the states and regions for the Lower House
}

\author{
Dean Jaensch with Narelle Miragliotta and Rae Wear ${ }^{1}$
}

\begin{abstract}
Analyses of Australian federal elections at the sub-national level are traditionally organised on the bases of the various individual states and territories. Such data provides a summary of party support and swings, and allows comparative analyses - but may mask significant differences in the patterns of party support within and across the state and territory borders. This chapter first provides a summary of the electoral contests in the states for the House of Representatives where government is decided, and then offers a detailed analysis of the election in Australia's main regions using electoral clusters. The chapter does not cover the electoral geography of the Senate vote.
\end{abstract}

\section{The elections fought in the states}

In January 2013, when Julia Gillard announced the 'longest campaign' in Australian history, the Labor Party appeared to be in a dire situation. Given that it had governed in a minority situation then for over two years, it could not afford to lose even one seat if it wished to retain government, and had to win seats from the Coalition if it wished to hold government in its own right. The national polls suggested either outcome would be an uphill battle.

At the start of 2013, Labor's primary vote was below its 2010 support in each of the five mainland states. The swing against Labor was least in Western Australia, but in the other states the slump was around minus 4 to 5 per cent, enough to send the Labor Party into the oblivion of opposition.

Eight months later, the swings were confirmed in the September 2013 election, with Labor suffering primary swings often well in excess of the pollsters' predictions. Labor suffered heavy primary swings in the states of Victoria

\footnotetext{
1 We acknowledge invaluable assistance in the preparation of this chapter from Antony Green, John Wanna, and Nick Economou.
} 
and Tasmania and, to a lesser extent, in South Australia. Despite the fears of the party that there could be a big loss in New South Wales, there was only a comparatively small swing of -2.8 per cent.

The format of the following table will be followed in the remainder of this chapter. It contains a summary of the primary vote, swing, and two-party vote for the Labor Party, the primary and two-party votes for the Coalition, as well as the primary support for the Greens, all in percentages of the votes cast.

Table 1: 2013 election results - patterns of party support, states and territories

\begin{tabular}{|l|r|r|r|r|r|r|r|r|}
\hline & \multicolumn{1}{|l|}{ NSW } & \multicolumn{1}{l|}{ Vic } & \multicolumn{1}{l|}{ Qld } & \multicolumn{1}{l|}{ WA } & \multicolumn{1}{l|}{ SA } & \multicolumn{1}{l|}{ Tas } & \multicolumn{1}{l|}{ NT } & \multicolumn{1}{l|}{ ACT } \\
\hline ALP primary & 34.50 & 34.80 & 29.80 & 28.80 & 35.70 & 34.80 & 37.40 & 42.90 \\
\hline ALP swing & -2.80 & -8.00 & -3.80 & -2.40 & -5.00 & -9.20 & -0.50 & -2.10 \\
\hline ALP two-party & 45.65 & 50.20 & 43.00 & 41.70 & 47.60 & 51.20 & 49.65 & 59.90 \\
\hline Coalition primary & 47.30 & 42.70 & 45.70 & 51.20 & 44.90 & 40.30 & 41.70 & 34.60 \\
\hline Coalition two-party & 54.35 & 49.80 & 57.00 & 58.30 & 52.40 & 48.80 & 50.35 & 40.10 \\
\hline Green primary & 7.90 & 10.80 & 6.20 & 9.70 & 8.30 & 8.30 & 7.90 & 13.40 \\
\hline
\end{tabular}

Source: Australian Electoral Commission (2013).

Labor lost 17 seats to the Coalition: eight in New South Wales, three in each of Victoria and Tasmania, two in Queensland, and one in South Australia. The other jurisdictions remained unchanged.

\section{The political contexts of the states}

The second section of this chapter focuses on regions, campaigns and policy foci in the states, and clusters of electorates which cross state boundaries and significantly different political environments. This section provides a summary of the electoral contexts of the states.

\section{New South Wales}

Electing 48 of the 150 seats in the House of Representatives made New South Wales crucial to both Labor and the Coalition. In 2013, to have any hope of retaining government, Labor needed to hold all of its New South Wales seats (26 held after the 2010 election). But to achieve this, it had to reverse the trend for the support of New South Wales Labor to lag behind its national vote.

In January 2013, Labor in New South Wales appeared in no shape to be a real contender in the election. It had been massacred in the state election in 2010, winning a meagre 25.6 per cent of the first preference votes, 35.8 per cent of 
the two-party votes, and was left with only 20 of the 93 seats in the Legislative Assembly. The fear that this landslide against Labor would be repeated was the prime reason the Labor Right faction(s) supported the change to Kevin Rudd in June 2013.

New South Wales Labor had been dysfunctional while in government and had infamously conducted a leadership rotisserie, involving four leaders over three years from 2008-11 (Premiers Morris Iemma, Nathan Rees, and Kristina Keneally and finally Opposition Leader John Robertson). In opposition after 2010 the party continued to be beset by problems: 'racked by voting anger at infrastructure deficiencies, ministerial scandals, and acrimonious internal conflict over privatisation of power' (Thompson and Robinson 2012: 173). Labor also feared that the continuing revelations of corruption in the Independent Commission Against Corruption (ICAC) hearings would seriously impinge on the federal election.

A January-March 2013 Newspoll reinforced a gloomy picture for Labor in New South Wales: the party was likely to receive only 33 per cent of the primary votes and 46 per cent of the two-party vote. An April-June Newspoll showed a further slump in Labor's primary support to 30 per cent. In two August Newspolls, one month before the election and following the reinstatement of Prime Minister Kevin Rudd, Labor's primary support recovered slightly, to 34 per cent, but the Coalition was comfortably ahead with a primary vote of 51 per cent.

One potential problem for Labor was the attitudes of residents of the western Sydney suburbs, the former site of 'Howard's battlers' after 1996, which had returned to federal Labor from 2004. Both Gillard and Rudd recognised this and gave the area close attention. Two focused Newspolls in August, only days out from the election, emphasised Labor's problem. One poll, in the western suburbs key seats of Parramatta, Reid, Banks, Lindsay and Greenway, found Labor on 34 per cent of the primary vote and the Coalition sitting on 52 per cent. The second, a mixed bag of Labor marginal seats - Dobell, Robertson, KingsfordSmith, Page and Eden-Monaro-produced a similar result: Labor 36 per cent, Coalition 48 per cent. These patterns suggested that the Coalition would not only hold its non-metropolitan seats, but it had the potential to erode Labor's seats in Sydney. It meant that Labor would have to look elsewhere to have any hope of retaining government.

The election confirmed the polls. A swing of -2.8 per cent saw Labor lose eight marginal seats to the Coalition: Banks, Barton, Dobell, Eden-Monaro, Lindsay, Page, Reid, and Robertson. 


\section{Victoria}

Victoria was for many years the 'jewel in the Liberal crown' but in the 1990s became a Labor stronghold. In the 1998 election, Labor won 53.5 per cent of the two-party vote and, with the exception of 49 per cent in 2004, maintained this level of support. In the 2010 federal election, Labor won the Victorian seats of McEwen and La Trobe from the Liberal Party, the only seats lost by the Coalition across Australia. Labor's primary vote in Victoria was 5 percentage points higher than its national vote, while the Liberal Party was 5 percentage points below.

In 2013, Victoria offered Labor an opportunity to overcome its potential losses in New South Wales. But the polls told a different story. A January-March Newspoll had Labor on 37 per cent of primary votes to the Coalition's 44 per cent. The April-June Newspoll showed a major slump in Labor's primary support to 29 per cent, with the Coalition on 46 per cent. At the state level, however, the Coalition Government had seen its one-seat majority disappear when one member decided to become an independent, and began a bitter war against the Liberal Speaker, Ken Smith. State Liberal politics descended into turmoil and an almost complete breakdown, reinforcing Labor's hopes of a positive effect on its 2013 chances.

The August Newspolls showed a narrowing of party fortunes: Coalition 39 per cent of primary votes, Labor 37 per cent. This was an encouraging trend for Labor, which even had the possibility of winning seats in Victoria to overcome any losses in New South Wales. But one week before the election, a Newspoll conducted in three key marginal electorates, La Trobe, Deakin, and Corangamite, provided evidence that Labor was in trouble where it mattered. The Labor Party was on 34 per cent of the primary vote, the Coalition 47 per cent. Further, Labor continued to face a strong challenge from the Left. The Green vote had increased from 7.5 per cent in 2004 to 8.2, and 13 per cent in the August poll. In 2010, the electorate of Melbourne saw Adam Bandt become the first Green member of the House of Representatives to win at a general election. Labor was forced to fight the 2013 election on two flanks.

In the election, Labor suffered a primary swing against it of -8.0 per cent, but Green preferences enabled it to achieve a two-party vote of 50.2 per cent. Despite the dire predictions from the polls, Labor lost only three seats to the Coalition: Corangamite, Deakin and La Trobe; but significantly failed to win back Melbourne from the Greens despite the Liberal Party directing its preferences to Labor ahead of Bandt. The Liberals only gained two seats net as they lost the rural seat of Indi with sitting member Sophie Mirabella defeated by the Independent Cathy McGowan (see Chapter 16). 


\section{Queensland}

'Queensland is a large, diverse, decentralised state with distinctive political geography and culture.' It is also a state with distinctive patterns of party support. Over the past few decades, it has been the case that 'Queenslanders have long been more reluctant than the rest of the nation to embrace federal Labor' (Ward 2012: 217). But Labor needed to do well in this northern state, as Queensland was crucial for Labor to balance its expected losses elsewhere. In early 2013, at the beginning of the campaign, it faced real problems. A similarly catastrophic result as occurred in New South Wales for Labor in the 2012 state election resulted in Labor's primary vote plummeting to 26.7 per cent, and the party was reduced to only seven of the 89 seats. Federal Labor was hoping that the 'Newman effect' would improve its outlook through voters' reactions to the financial cutbacks, the personal style of the premier, and the government's internal problems of transparency and accountability.

However the polls showed a bleak picture. A Newspoll in January-March showed federal Labor with a primary vote of 30 per cent, to 49 per cent for the Coalition's Liberal National Party (LNP). Over the next six months, the picture remained gloomy for the ALP. The return of 'I'm Kevin Rudd from Queensland' to the prime ministership was crucial for any hopes to reverse the trend. It did to a degree, with the August Newspoll showing Labor with 37 per cent of the primary vote to 46 per cent for the LNP. But this was not enough. On polling data, the ALP would be left holding two or three seats at the most and, two weeks before polling day, there were even suggestions that Rudd would lose his own seat.

In the final week before the election, Newspoll conducted a survey in seven marginal seats: Blair, Lilley, Moreton, Oxley, Petrie, Rankin and Capricornia. The overall primary votes were Labor 38 per cent, Coalition 42 per cent, and Greens 8 per cent. This suggested that these marginal Labor seats could go either way. But a further Newspoll in the key marginal seats of Brisbane, Forde, Longman, Herbert, Dawson, Bonner, Flynn, and Fisher produced an overall party support of Labor 32 per cent, LNP 54 per cent, and Greens 10 per cent.

The political battle was fought over the issue of which leader could exert the greater influence. Kevin Rudd campaigned as a local 'Queenslander', and Labor's hope was that his leadership would produce a better result than a potential loss of all seats under Gillard. On the other hand, the policies of LNP Premier Campbell Newman, involving savage cuts in almost every government area, had the potential to wash over to the federal context, especially once Tony Abbott made statements regarding cuts to the public service. But in the final analysis, 
it appeared that federal Labor was depressing Queensland Labor more than the state LNP was boosting Labor, and Queenslanders seemed to have 'got over' the cuts made by the Newman LNP Government (Wear 2013).

Two other complicating factors emerged. Queensland's maverick sitting member Bob Katter announced he was leading a charge across Australia to win seats for Katter's Australian Party. Meanwhile, Queenslander Clive Palmer announced a full team of candidates for his newly created Palmer United Party. Katter's intervention had the potential to damage the LNP; the possible effects of Palmer's intervention were less clear.

The electoral geography of Queensland also provided more hope for the LNP than for Labor. Of the nine electorates in the rural and provincial city areas, seven were held by the LNP, one (Capricornia) by Labor, and one by Katter. There was no real prospect of Labor increasing its representation in those seats. Of the 13 electorates in the metropolitan area, the LNP held eight to Labor's five. That was the key arena for Labor, not only for the Queensland result. As in Victoria, Labor had to at least hold all of its Queensland seats, and hope to increase its representation, to balance what was expected in New South Wales. In the event, Labor lost Capricornia and Petrie, and Palmer narrowly won Fairfax from the LNP.

\section{Western Australia}

The 2010 federal election had 'affirmed Western Australia's recent status as a conservative heartland state and one of the ALP's most unforgiving electorates' (Miragliotta and Sharman 2012: 231). For 30 years, Labor's share of the vote in federal elections had been lower than its performance at the state level, and had been declining. One long-term factor was the west's traditional animosity towards Canberra, regardless of party politics, but especially pronounced under a Labor federal government. The 2013 context was dominated by the perceived effects of the Gillard mining tax, and a potent argument from the WA Premier, Colin Barnett, that the state was being sold out under the GST distribution.

The 2010 election had left Labor with only three of the 15 seats. Further, Labor's primary vote of only 31.2 per cent was the lowest of any state or territory, and it had to depend on Green preferences to hold Brand, Fremantle and Perth. The polls during 2013 showed Labor's support continuing to decline. Over three Newspolls during 2013, Labor's primary support was 31, 25 and 30 per cent, with the Coalition holding an absolute majority on 50, 55 and 52 per cent.

A focused Newspoll in March emphasised the bleak picture for Labor. In the metropolitan area, the Liberal Party held a primary vote advantage over Labor of 50 to 35 per cent. In the rural areas, the margin was 66 to 24 per cent. Faced 
with a potential wipeout, Labor put all of its resources into attempting to save its three seats. It succeeded, despite the fact that Labor's state-wide two-party vote was the lowest in Australia, at 41.7 per cent. The campaign for marginal seats succeeded to the point where there was even a slight increase in Labor's primary vote in Fremantle. The only seat change was $\mathrm{O}^{\prime}$ Connor, which, with the retirement of the Nationals' Tony Crook, shifted back to the Liberals in a threecornered contest.

\section{South Australia}

South Australia did not promise to be important in the 2013 election. Of its 11 seats in the House of Representatives, five were held by the Liberal Party, and six by Labor. Three seats were marginal, all Liberal-held. But, given the evidence from the polls, Sturt, Boothby and Grey were likely to be retained.

The 2010 state election had seen massive swings against the Rann Labor Government, with swings of double figures recorded in the safe seats held by Rann ministers. However Rann was returned on the basis of an intense campaign, in key Labor marginals. The replacement of Rann by Jay Weatherill was a deliberate attempt to excise the Rann legacy and his style, and rebuild support in the metropolitan area. But under Weatherill, Labor faced a depressed economy, critically ill public finances, a depleted treasury, high unemployment - the second worst in the country after Tasmania-and a generally sullen electorate. The decision by BHP Billiton to postpone its Roxby Downs expansion, and the constant talk of the closure of the Holden car manufacturing plant, did not help Labor's standing; nor did the decision of Standard and Poors to reduce the state's rating from $\mathrm{AA}+$ to $\mathrm{AA}$.

In three Newspolls in 2013, Labor primary support was 32, 30 and 32 per cent, with the Liberal Party on 41, 44 and 46 per cent. This was not encouraging for Labor, but there was a buffer in its favour. All of its five seats were held by solid margins, and would be difficult for the Liberal Party to pick off. In the final analysis, Labor lost its most marginal seat Hindmarsh to the Liberal Party, with a two-party swing of 8 per cent.

\section{Tasmania}

The island state contains five electorates: Bass (based on Launceston), Denison and Franklin (Hobart), and two rural electorates - Braddon and Lyons. In the 2007 election, Labor won all five seats in the House of Representatives and in 2010 Labor retained four of the five, with independent Andrew Wilkie winning 
Denison. This result prompted one analyst to comment that: 'The Liberal Party in Tasmania is at a crossroads over its capacity to attract both the voting public and candidates who can connect with the constituency' (McCall 2012: 208).

But neither Labor nor the Greens were in good odour in Tasmanian politics. The Labor-Green coalition Government, formed after the 2010 state election, had not succeeded in revitalising the state. The economy was the worst-performing of the states, with the highest unemployment level and little investment, while being increasingly dependent on federal largesse.

Labor's slim chances rested on the Greens continuing their meteoric rise in support: increasing from 9.9 per cent in the 2004 federal election to 13.5 per cent in 2007, and 16.8 per cent in 2010. The hope was that the Greens could pick up solid proportions of primary votes and feed them through to Labor. But a poll by Enterprise Marketing and Research Services on state voting intentions just prior to the 2013 election showed Labor with a primary vote of 23 per cent, Liberal 44 per cent, and Greens 12 per cent, with 17 per cent undecided.

After the 2013 election, it appears that the Liberal Party has moved past the crossroads McCall described by winning Bass, Braddon and Lyons. The Labor Party was reduced to only one seat, Franklin, where the primary swing against Labor was only 2.9 per cent, compared to the state-wide swing of 9.2 per cent. Andrew Wilkie was returned in Denison, with a swing in his favour of 16.8 per cent. The results indicated that Labor now had the problem of evaporating support especially in rural areas: a 9 per cent first-preference swing against Labor in Bass, -11.1 percent in Braddon, -11 per cent in Denison, and -12.1 per cent in Lyons. Overall, Labor suffered a state-wide two-party swing of -11.3 per cent, while the Greens lost more than half of their 2010 vote, falling from 16.8 to 8.3 per cent.

\section{Northern Territory}

The Northern Territory is a unique region. It had a population of 231,331 at the 2011 census, of which 26.8 per cent were Aboriginal or Torres Strait Islanders. There are two electorates in the territory. Solomon covers the city of Darwin and the satellite city of Palmerston. It was created in 2001, and was won by the Country Liberal Party (CLP) in 2001, 2004 and 2010, and by Labor in 2007. Lingiari comprises the remainder of the territory, including the Christmas and Cocos Islands. Forty-three per cent of Lingiari's population are Aboriginal and Torres Strait Islanders. This makes it unique in Australia. Labor has held the seat from its formation in 2001 on the back of very strong support from Indigenous voters. Until the 2013 election, Labor's Indigenous constituency had easily overcome solid support for the CLP in Alice Springs and Katherine. This 
hegemony was tested in the 2010 federal election when Labor only narrowly retained Lingiari, surviving a swing of -13.9 per cent against the incumbent, Warren Snowden, even though the CLP's vote was almost unchanged, with a swing against it of only -0.4 per cent.

The 2012 election for the territory Assembly produced a result that was a surprise to everyone. Since the first Assembly election in 1974, the outback electorates, which define Lingiari, had been the heartland of the Labor Party. For the first time since 1974, when Labor won no seats, the Aboriginal voters swung heavily to the CLP, which won five of the seven seats.

The CLP had hopes that the seat of Lingiari would repeat this swing at the 2013 federal election, partly through the support and efforts of two Aboriginal women members of the Assembly. Bess Price is a highly respected elder, who has been outspoken in favour of the federal intervention in the Aboriginal communities. Alison Anderson had won her seat of Macdonnell in 2008 as a Labor member, and was re-elected in 2012 as a CLP member. Both were highly respected in Aboriginal communities, and were expected to bolster the CLP vote.

However, serious instability in the CLP Government, which included the removal of Alison Anderson from her ministerial position, along with a lack of achievement by the CLP to produce what it had promised for the outback communities, resulted in the Labor Party narrowly holding onto the seat of Lingiari with a two-party swing of -2.82 against the sitting member. The CLP also narrowly retained Solomon.

\section{Australian Capital Territory}

The Australian Capital Territory is essentially the city-state of Canberra. Both of its electorates are Labor heartlands, with strong support from the overwhelmingly dominant component of the population - the Australian public service. The Labor Party has never been under any real threat. In the past five federal elections, the two-party Labor vote has fluctuated between a low of 61.1 per cent in 2001 to 63.4 per cent in 2007. Given fears over public service cuts, there was little doubt that such results would be repeated, and in 2013, the electorates of Canberra and Fraser produced a two-party vote of 57.0 per cent and 62.6 per cent respectively.

\section{A regional analysis}

The most obvious regional division in Australia is between the metropolitan and non-metropolitan areas. The rural electorates are almost exclusively the province of the Coalition, shared between the Liberal and National parties. The 
metropolitan areas have traditionally been the arena for a two-party contest between Labor and Liberal parties but, in recent elections, the Greens have intervened. The 2013 election result again demonstrated this regional division.

Table 2: Patterns of party support, metropolitan and non-metropolitan

\begin{tabular}{|c|c|c|}
\hline & Metropolitan & Non-metropolitan \\
\hline Labor primary & 36.20 & 29.40 \\
\hline Labor swing & -4.00 & -5.40 \\
\hline Labor two-party & 49.40 & 42.40 \\
\hline Coalition primary & 43.90 & 47.80 \\
\hline Green primary & 10.00 & 6.80 \\
\hline
\end{tabular}

Source: Australian Electoral Commission (2013).

Of 63 electorates in the non-metropolitan region, Labor held 23 in the run-up to the 2013 election; it retained only five. In the metropolitan region, Labor held 49 seats prior to the election; it retained 39.

This division between metropolitan and non-metropolitan regions masks important sub-regions, which have differing socio-economic characteristics and different patterns of party support. To extend and refine the analysis, the focus will be on clusters of similar electorates across Australia, defined by the Australian Electoral Commission (AEC). There are:

- Rural cluster: divisions without a majority of enrolment in major provincial cities (43 divisions in 2013);

- Provincial cluster: divisions with a majority of enrolment in major provincial cities (20 divisions);

- Inner metropolitan cluster: located in a capital city, and comprising wellestablished, built-up suburbs (44 divisions); and the

- Outer metropolitan cluster: located in capital cities and containing areas of more recent urban expansion (43 divisions).

Our regional analysis is based on these clusters of electorates in the six states. The Northern Territory, with two electorates, can be regarded as a region in its own right, defined especially by the fact that its population includes over 25 per cent Aboriginal people, and the lack of a sizeable metropolitan area. The Australian Capital Territory, essentially the city of Canberra, also has a unique socio-economic structure.

In terms of numbers of seats, the key to winning elections in Australia, except in the case of a very tight election, as in 2010 which resulted in a hung parliament, are the metropolitan areas. Of the 150 electorates in this analysis, 87 are in the metropolitan areas. 
Table 3: Patterns of party support by clusters

\begin{tabular}{|l|r|r|r|r|r|}
\hline & \multicolumn{1}{|l|}{ Inner metro } & \multicolumn{1}{l|}{ Outer metro } & \multicolumn{1}{l|}{ Provincial } & \multicolumn{1}{l|}{ Rural } & \multicolumn{1}{l|}{ Total } \\
\hline Labor primary & 35.70 & 36.80 & 35.50 & 26.00 & 33.40 \\
\hline Labor swing & -3.10 & -4.20 & -6.60 & -5.00 & -4.60 \\
\hline Labor two-party & 48.20 & 48.10 & 48.60 & 40.20 & 46.60 \\
\hline Coalition primary & 43.40 & 44.10 & 44.30 & 48.40 & 45.60 \\
\hline Green primary & 12.10 & 7.30 & 7.40 & 6.80 & 8.70 \\
\hline
\end{tabular}

Source: Australian Electoral Commission (2013).

The most obvious aspect in this data is the relatively low variations of patterns of voting across the first three subsets. The rural cluster is the sole outlier, as would be expected, and showed by far the lowest Labor vote and the highest support for the Coalition. This cluster is the heartland of the Liberal and National parties. Yet, the patterns across the metropolitan and provincial clusters were remarkably similar on three indices: Labor primary and two-party vote, and Coalition primary vote. This looks, at first sight, to offer support for a thesis of a relatively uniform vote and swing. But the relative similarity was the result of significantly different primary swings. The swing against Labor in the provincial cluster was significantly higher than in the two metropolitan clusters. The Green vote was significantly higher in the inner metropolitan cluster. These differences are explored below.

\section{The rural cluster}

This cluster comprises 43 electorates across the six states. New South Wales (14 electorates), Victoria (9) and Queensland (10) dominate the cluster, with Western Australia (4), South Australia (3) and Tasmania (2), as well as Lingiari in the Northern Territory.

This cluster is, and always has been, essentially non-Labor territory. For decades, the electoral story of rural Australia was relatively simple: the overwhelming majority of rural seats were won by either Liberal or National candidates. The Coalition agreement under which incumbents of both parties were protected from contests with each other provided a relatively stable outcome. Moreover, the recent formation of the Liberal National Party ended internal coalition conflicts in Queensland, and there is no National Party to contest in Tasmania, and no coalition in South Australia. Outside Queensland, the National Party, holding nine rural seats in New South Wales and Victoria, faces the real potential of contests with the expansive Liberal Party in vacant rural seats, although preferencesharing agreements ensure that the Coalition vote remains relatively stable. 
The emergence of new issues particularly relevant to rural areas has produced some tensions: the carbon tax; the mining tax; water supply and security, and coal seam gas developments, international trade and marketing, have the potential to divide the Coalition in the rural areas. More recently, the election context in rural areas has become more complex, with the success of conservative-inclined independents and the formation prior to the election of both Katter's Australian Party (KAP) and the Palmer United Party (PUP). All these developments had the potential to erode Coalition support in rural areas, especially in Queensland where Bob Katter is a formidable incumbent and a former National member.

Table 4: Patterns of party support, rural cluster

\begin{tabular}{|l|r|r|r|r|r|r|r|r|}
\hline & \multicolumn{1}{|l|}{ NSW } & \multicolumn{1}{l|}{ Vic } & \multicolumn{1}{l|l|}{ Qld } & \multicolumn{1}{l|}{ WA } & \multicolumn{1}{l|}{ SA } & \multicolumn{1}{l|}{ Tas } & \multicolumn{1}{l|}{ NT $^{*}$} & \multicolumn{1}{l|}{ Cluster } \\
\hline ALP primary & 28.20 & 24.30 & 25.20 & 21.00 & 27.10 & 37.20 & 39.80 & 26.00 \\
\hline ALP swing & -4.50 & -7.70 & -6.10 & -2.20 & -5.80 & -9.50 & -0.30 & -5.00 \\
\hline ALP two-party & 40.10 & 38.80 & 41.30 & 35.20 & 40.10 & 47.40 & 53.70 & 40.20 \\
\hline Coalition primary & 51.90 & 52.80 & 45.70 & 60.00 & 50.00 & 46.90 & 38.20 & 48.40 \\
\hline Green primary & 7.20 & 6.10 & 5.30 & 7.80 & 7.70 & 8.30 & 7.80 & 6.80 \\
\hline
\end{tabular}

*Lingiari. Note that in this and following tables, some sub-clusters contain only a small number of electorates.

Source: Australian Electoral Commission (2013).

Across the rural cluster as a whole, Labor suffered a sizeable mean primary swing against it of -5.0 per cent, with the worst swings in the states of Tasmania (-9.5), Victoria (-7.7) and Queensland (-6.1), but only -2.2 in Western Australia. The Coalition achieved a mean primary swing in its favour of 1.6 per cent. The mean first preference Green vote in the rural cluster was 6.8 per cent, compared to 9.7 per cent in 2010, with the highest support in the electorate of Richmond (NSW) of 17.7 per cent.

The mean primary swing to the Coalition (LNP) was weakest in Queensland, with five of the 10 electorates showing a swing away from the LNP. The main cause was the support won by the PUP and, to a much lesser extent, the KAP (see the chapter by King). The PUP won a total of 13.6 per cent of the primary vote across the cluster, including 26.5 per cent in the electorate of Fairfax. The KAP won 4.7 per cent of the vote across the cluster, although their leader, Bob Katter, suffered a swing of 14.2 per cent to the LNP, and his primary vote was reduced to 29.4 per cent.

The electoral domination by the Coalition parties has come under attack from independents. The 2010 election produced three independents from safe Coalition rural seats, all of whom were formerly National Party members of parliament: Bob Katter in the Queensland electorate of Kennedy; Tony Windsor 
in New England and Rob Oakeshott in Lyne, both New South Wales rural seats. Windsor and Oakeshott gave their support to the Gillard/Rudd governments, and their retirement from the parliament at the 2013 election pre-empted their almost certain defeat in what were conservative electorates. The Nationals regained both seats. However, the persistence of the independent challenge in these electorates was highlighted in the Victorian rural seat of Indi, where Cathy McGowan ousted the Liberal's Sophie Mirabella who had held the seat since 2001 (see Chapter 16 by Costar and Curtin).

In the 2010 election, the Greens were described as 'harvesting votes and directing preferences in ways that might yet prove difficult for conservative rural MPs' (Woodward and Curtin 2012: 241). In 2013, the harvest was poor. The mean Green primary vote across the 10 rural electorates in Queensland fell from 10 per cent to 5.2 per cent. In the other states, the rural swing against the Greens was more subdued, with six of the rural electorates showing a small swing to the Greens-five in New South Wales.

Labor lost only one rural seat in New South Wales (Eden-Monaro) and two in Tasmania (Braddon and Lyons). Following the election, 34 of the 43 rural electorates are firmly in Coalition control. In a sense, five of the six Labor rural electorates constitute a sub-cluster. Lingiari has been analysed above. The Labor Party retained Richmond and Hunter in New South Wales, Blair in Queensland, McEwen in Victoria, and Wakefield in South Australia. In each of these rural Labor seats, there is a solid industrial/urban component; and in four of the five there was a strong swing against Labor (the exception was Blair with only a -0.5 per cent swing). Hence, the 2013 election reduced all five to marginal status. Across rural Australia there were significant swings against Labor, namely in Hunter (-9.8 per cent), McEwen (-10.2 per cent), Braddon (-11.1 per cent) and Lyons (-12.1 per cent). Queensland produced two rural independents: Bob Katter who was re-elected in Kennedy and Clive Palmer won Fairfax; both seats were previously held by the Nationals.

The patterns of support across the rural cluster imply stability rather than change in 2013. The swings against Labor in the rural cluster suggest that Labor has a difficult task holding its few rural seats. The fact that there was a primary swing against Labor in every rural electorate except Lyne and New England (where the incumbent independents had retired) and a 0.1 per cent swing in $\mathrm{O}^{\prime}$ Connor, suggests that the rural cluster has become even more reinforced as the heartland of non-Labor parties.

\section{The provincial cluster}

There are 20 electorates classified as provincial by the AEC, on the basis that a majority of the enrolment is in major provincial cities. Eight are in New South 
Wales, seven in Queensland, four in Victoria, and one (Bass) in Tasmania. This cluster is the most diverse in socio-economic terms and there is a significant party division between them. Prior to the election, seven of the eight provincial electorates in New South Wales were held by Labor, as were all four in Victoria, and Bass. Only one of the seven in Queensland was Labor. This contrasting pattern of party support suggests that the differing political contexts in the states had a significant influence on the provincial cities.

The 2013 election saw five provincial seats transferred from Labor to the Coalition, the highest proportion across the four clusters: Dobell and Robertson in New South Wales, both on the central coast; Corangamite in Victoria, including the southern coast but extending to the suburbs of Geelong; Capricornia in Queensland, including suburbs of Rockingham and Mackay; and Bass in Tasmania, centred on Launceston. This result meant that the Coalition now holds all of the provincial seats in Queensland, the sole seat in Tasmania, and four of the 12 provincial seats in New South Wales and Victoria. Further, the swings against Labor have reduced the security of the remaining Labor-held seats to a significant degree.

Labor's loss of the seat of Dobell was an expected outcome: the incumbent Craig Thomson faced charges of fraudulently misusing union funds for personal benefit including for the procurement of prostitutes; he had remained loyal to the Gillard Government but been suspended then expelled from the Labor Party. The replacement Labor candidate then suffered a primary swing against her of -11.2 per cent. All five electorates lost by Labor were all marginal prior to the election, meaning any general swing away from Labor would be enough to see the seat change hands.

Table 5: Patterns of party support, provincial city cluster

\begin{tabular}{|l|r|r|r|r|r|}
\hline & \multicolumn{1}{|l|}{ NSW } & \multicolumn{1}{l|}{ Vic } & \multicolumn{1}{l|}{ Qld } & \multicolumn{1}{l|}{ Tas } & \multicolumn{1}{l|}{ Cluster } \\
\hline Labor primary & \multicolumn{1}{|l|}{41.30} & 38.50 & 27.20 & 34.70 & 35.40 \\
\hline Labor swing & -5.30 & -8.70 & -5.80 & -8.80 & -6.30 \\
\hline Labor two-party & 54.30 & 52.50 & 40.00 & 46.00 & 51.30 \\
\hline Coalition primary & 38.10 & 40.30 & 43.00 & 47.90 & 41.40 \\
\hline Green primary & 8.00 & 9.50 & 4.70 & 7.90 & 7.20 \\
\hline
\end{tabular}

Source: Australian Electoral Commission (2013).

The Queensland result in the provincial cities was significantly worse for Labor than in New South Wales or Victoria. The mean Labor primary vote was a meagre 27.2 per cent across the seven electorates. The 2013 election produced a clean sweep for the LNP when it won Capricornia from Labor. Further, after the 
mean swing to the LNP of 5.8 per cent, six of the seven Queensland provincial electorates are now safe for the Coalition, with only Capricornia in a marginal LNP status.

The overall swing against Labor across the cluster was especially marked in Victoria. Three of the four provincial electorates in Victoria, Ballarat, Bendigo and Corio, were previously safe Labor, but the election result reduced this to marginal status. In New South Wales, seven of the eight provincial electorates were held by Labor prior to the election, all but Dobell and Robertson with safe margins. Both these seats were lost to the Liberal Party. Support for the Greens in the provincial cluster was relatively strong in New South Wales, Victoria, and Bass in Tasmania, but significantly weaker in Queensland. The Greens suffered a mean primary swing against them of -3.5 per cent across the cluster.

Provincial electorates, by definition, contain all or part of major provincial cities. In the Victorian case, the four cities can be considered to be closely related to greater Melbourne: Corangamite and Corio in Geelong; Ballarat and Bendigo as major cities. In New South Wales, three of the eight provincial cities (Macquarie, Dobell and Robertson) have all but been absorbed into greater Sydney, while Charlton, Newcastle, Shortland, Cunningham and Throsby are located in the Newcastle and Illawarra areas.

In Queensland, four of the seven provincial cities are not as geographically linked to the capital, as similar seats are in Victoria and New South Wales, but are 'country provincials', namely: Capricornia (Rockhampton), Groom (Toowoomba), Herbert (Townsville), and Hinkler (Bundaberg). These hinterland electorates are closely connected with the rural areas surrounding them, and reflect the political culture of rural Queensland. Three provincial electorates are in the rapidly growing population area between Brisbane and the Gold and Sunshine Coasts. These three are embedded in different socio-economic conditions than in the more 'metropolitan' electorates in Victoria and New South Wales.

The Coalition secured a mean swing of 2.6 per cent in its favour in the four Victorian electorates. The mean swing against Labor was -8.7 per cent, with highs of -10.4 per cent in Bendigo and -9.8 per cent in Ballarat. In New South Wales, there was almost no movement in the mean swing to the Coalition across the eight electorates, with Shortland and Newcastle showing the highest swings (-3.5 and -3.4 per cent respectively). But in Queensland, there was a mean swing of -4.0 per cent against the LNP. This is explained by the involvement of the PUP and, to a lesser extent, the KAP. The mean PUP primary vote over the seven electorates was 12.3 per cent, with the highest in Hinkler, 17.7 per cent. The KAP contested five of the Queensland provincial electorates with a mean primary vote of 4.9 per cent. 
On the data examined, it is fair to say that the provincial city electorates better reflect the political contexts of the states than the other clusters. For example, of the 12 NSW and Victorian provincial electorates, Labor holds eight after the election. All seven Queensland provincial electorates are firmly in the hands of the LNP. Overall, this reinforces the impact of location within this sub-cluster. The more 'metropolitan' provincial cities appear to be moving closer to the metropolitan patterns of voting.

\section{Metropolitan areas}

Given the rural and provincial clusters offered slim pickings for Labor and, in fact, saw Labor lose seats - it was the metropolitan areas which would decide Labor's fate. A January-March Newspoll indicated that Labor was in trouble in the capital cities: 45 per cent Coalition, 35 per cent Labor. This pattern was repeated in the April-June and August Newspolls. The data suggested that there would be a major swing against Labor in Sydney, especially in the western suburbs; that Adelaide and Melbourne were weakening for Labor; and that Perth may produce a result where Labor lost all of its seats. The implication was that Brisbane had to produce a solid swing to Labor to counteract the losses elsewhere.

Table 6: Patterns of party support, metropolitan areas

\begin{tabular}{|l|r|l|r|r|r|r|r|r|r|}
\hline & \multicolumn{1}{|c|}{ NSW } & Vic & \multicolumn{1}{l|}{ Qld } & \multicolumn{1}{l|}{ WA } & \multicolumn{1}{l|}{ SA } & \multicolumn{1}{l|}{ Tas } & \multicolumn{1}{l|}{ ACT } & NT * & Cluster \\
\hline ALP primary & 35.90 & 38.20 & 34.80 & 30.60 & 40.70 & 32.50 & 42.90 & 35.40 & 36.40 \\
\hline ALP swing & -2.00 & -8.10 & -1.50 & -2.60 & -4.50 & -6.90 & -2.10 & -0.70 & -3.90 \\
\hline ALP two-party & 46.30 & 54.50 & 47.10 & 43.30 & 51.90 & 57.00 & 40.10 & 48.30 & 49.20 \\
\hline Coalition primary & 48.00 & 39.00 & 44.80 & 49.10 & 41.40 & 31.10 & 34.60 & 44.70 & 44.30 \\
\hline Green primary & 8.40 & 12.70 & 7.80 & 10.20 & 8.90 & 10.10 & 13.40 & 8.00 & 10.00 \\
\hline
\end{tabular}

*Solomon.

Source: Australian Electoral Commission (2013).

Western Australia produced the lowest mean primary vote for Labor in the metropolitan areas, and Franklin (Tasmania) the highest. The primary swing against Labor was by far the most pronounced in Victoria.

In New South Wales, with 26 metropolitan seats, 15 were held by Labor, eight of which were marginal. The Labor Party was fearful that the corruption scandals that had led to a landslide in the New South Wales election, and which were continuing, would result in a similar result in the federal election. There were also suggestions that Labor's new, hard-line policy on boat people could have a major effect, especially in the western suburbs of Sydney. Coupled with negative reactions from this region concerning the Rudd proposal for a 'big Australia', this had the potential to produce a backlash against Labor. But the 2013 election 
saw Labor hold up better than predicted. The New South Wales swing against Labor was merely the second lowest after Queensland, and was only half of the mean swing across the cluster.

\section{The 'ethnic' sub-cluster}

As Jupp notes in Chapter 19, there were 14 electorates in Sydney which he labels 'ethnic electorates', containing 25 per cent or more people who used a language other than English at home. All but one (Bennelong) was held by the Labor Party. Nine electorates were in the western suburbs. Of these, three were lost to the Coalition: Banks (-1.9 per cent swing against Labor), Barton (-8.0 per cent) and Reid (-0.9 per cent). In fact, five 'ethnic' electorates showed a swing to Labor: Greenway, Chifley, Grayndler, Blaxland, and Fowler, the last with a two-party swing of 8 per cent. It was evident that the deep concern of the Labor Party that it would lose heavily in Sydney's west was tempered by the small swing against it, despite the loss of ('non-ethnic') Lindsay.

In Melbourne, which had held up for Labor in 2010, there were also suggestions in the polls that Labor support was weakening, and that the Greens would erode Labor support. The former proved to be the case, with a primary swing of -8.1 per cent across the Melbourne metropolitan electorates, although Labor still finished with a two-party vote of 54.5 per cent. The Green vote fell by 1.5 per cent from 2010, but the preference flow to Labor was still decisive. Labor lost only two seats in metropolitan Melbourne (Deakin and La Trobe) both of which were marginal before the election.

The influence of 'ethnic' communities on the metropolitan vote in Sydney and Melbourne showed a significantly different pattern. Of 15 Melbourne-based 'ethnic' electorates, Menzies was retained by the Coalition, and Melbourne itself was retained by the Greens. In the remaining 13, the mean primary vote for Labor was 61 per cent, compared with 53.9 per cent in the Sydney 'ethnic' electorates. A further significant difference between the two 'ethnic' groups was the difference in the Green vote. This reflected the higher proportion of Green support across Melbourne and Victoria as a whole.

Table 7: Patterns of party support, 'ethnic' electorates

\begin{tabular}{|l|r|r|}
\hline & Sydney & \multicolumn{1}{|l|}{ Melbourne } \\
\hline Labor primary & 45.80 & 43.10 \\
\hline Labor swing & -0.70 & -9.20 \\
\hline Labor two-party & 55.10 & 58.50 \\
\hline Coalition primary & 42.30 & 33.10 \\
\hline Green primary & 6.50 & 12.40 \\
\hline
\end{tabular}

Source: Australian Electoral Commission (2013). 
In terms of seats won and lost, the metropolitan areas produced less change than both Labor and the Coalition had predicted. Labor lost eight of the 46 seats it had held: Banks, Barton, Lindsay and Reid in Sydney; Deakin and LaTrobe in Melbourne; Petrie in Queensland, and Hindmarsh in Adelaide. Despite the suggestions in the early polls of 2013, there was no landslide in the metropolitan areas; the swing against Labor was a modest -4.0 per cent.

Nor was there strong evidence of uniformity within the metropolitan cluster. There were different patterns across the state sub-clusters. This is to be expected, as the effects of different state-oriented campaigns, issues and political contexts come into play. The strong swings against Labor in Melbourne, Hobart and Adelaide are prime examples.

\section{The inner metropolitan cluster}

This cluster contains 44 electorates across the capital cities. Prior to the election, Labor held 26 of these, with Melbourne held by the Greens and Denison held by independent Andrew Wilkie.

In recent years, these electorates, especially in Sydney and Melbourne, have increasingly become the home for a specific socio-economic group, with a 'concentration of tertiary-educated, human-services-employed, young and affluent voters with social-progressive post-materialist outlooks' (Economou 2012: 184). These have become a heartland for the Greens, and a troubled cluster for the Labor Party. But the result of the 2013 election in the trendy innercity cluster was a matter of relative stability rather than change. Only four Labor seats were lost to the Coalition, and the mean swing against Labor was -3.1 per cent.

Table 8: Patterns of party support, inner metropolitan cluster

\begin{tabular}{|l|r|l|r|l|r|r|r|r|r|}
\hline & \multicolumn{1}{|l|}{ NSW } & Vic & \multicolumn{1}{l|}{ Qld } & \multicolumn{1}{l|}{ WA } & \multicolumn{1}{l|}{ SA } & \multicolumn{1}{l|}{ Tas } & \multicolumn{1}{l|}{ ACT } & \multicolumn{1}{l|}{ NT* } & Cluster \\
\hline ALP primary & 35.80 & 36.10 & 36.30 & 30.50 & 39.90 & 24.80 & 42.90 & 35.40 & 35.70 \\
\hline ALP swing & -1.70 & -7.80 & 0.50 & -1.40 & -4.90 & -11.00 & -2.10 & -0.70 & -3.10 \\
\hline ALP two-party & 42.30 & 53.40 & 49.50 & 43.40 & 51.50 & 45.00 & 59.90 & 48.30 & 48.20 \\
\hline Coalition primary & 47.60 & 38.20 & 43.80 & 49.70 & 42.30 & 23.20 & 34.60 & 44.70 & 43.40 \\
\hline Green primary & 10.40 & 18.20 & 10.70 & 11.90 & 9.30 & 7.90 & 13.40 & 8.00 & 12.10 \\
\hline
\end{tabular}

${ }^{*}$ Solomon.

Source: Australian Electoral Commission (2013).

With the exception of Denison (Hobart) and Perth, Labor's primary vote was remarkably similar across the cluster, with the lowest support in Perth, and (with the exception of Canberra), the highest in Adelaide. But this apparent 
similarity was a result of significantly different swings. In Brisbane, Sydney and Perth, Labor's primary vote was within 2 percentage points of the 2010 result. The expectation of strong swings against Labor did not eventuate. In Brisbane, there was a small primary vote swing in favour of the Labor Party, a result that was not expected by either side just weeks before the election. The Melbourne sub-cluster produced the strongest swing against Labor, but this did not bolster the Coalition to a significant degree.

The inner metropolitan areas were reinforced as the Green heartland, with a mean primary support across the cluster of 12.1 per cent. But, apart from Melbourne, it was a heartland that eroded significantly in 2013. The Greens lost one-third of their 2010 support in Brisbane, and one-quarter in Perth, Adelaide and Sydney. Melbourne alone was the standout result for the Greens.

The pattern of relative stability was reinforced by the fact that only four of the 44 inner-city seats shifted from Labor to Liberal: Reid, Banks and Barton in Sydney, and Hindmarsh in Adelaide. Despite the predictions of a dire result for Labor, there was no change in party representation in Melbourne, Brisbane and Perth. In Brisbane, Labor held on to its marginal seats in Lilley and Moreton, with a swing to Labor in the latter. In Perth, Labor's marginals, Fremantle and Perth, both recorded a slight swing to Labor. In Adelaide, Labor lost its most marginal seat, Hindmarsh, but retained Adelaide and Port Adelaide.

In Melbourne, with 12 electorates in the inner metropolitan cluster, there were strong swings against Labor in every electorate, a mean of -7.8 per cent, by far the highest in the cluster. But no seats were lost, partly because the largest swings occurred in the safest Labor electorates and, more important, the Green vote held up strongly and fed preferences to Labor. The mean swing against the Greens in Melbourne inner metropolitan area was a miniscule - 0.2 per cent. Labor was certainly saved by the Greens.

In the run-up to the election, there were expectations of a strong swing against Labor in Sydney, especially in the western suburbs. Of the 15 electorates in the inner metropolitan cluster of Sydney, six were held by the Liberal Party, five of which were safe: Bradfield, Cook, North Sydney, Warringah and Wentworth. Only one, Bennelong, was marginal. On the other hand, six of the nine Labor seats were marginal: Banks, Barton, Grayndler, Kingsford Smith, Parramatta, and Reid. Twelve of the 15 electorates swung against Labor; whereas Blaxland, Grayndler and Sydney, all safe Labor seats, showed a swing to the Labor Party. Labor lost only three seats: Banks, Barton and Reid-a result that was not expected by either side of politics. The western suburbs did not produce the anti-Labor swing to the extent that Labor feared and the Coalition hoped. 
The inner metropolitan cluster showed significant differences in swings: a small swing to the Labor Party in Brisbane; small swings against Labor in Sydney and Perth; a significant swing against Labor in Adelaide, and a very strong swing against Labor in Melbourne. In the single electorate of Denison in Hobart, Labor's primary vote was significantly depressed by support for the independent Andrew Wilkie, and the Perth inner metropolitan electorates produced a significantly lower primary vote. But Sydney, Melbourne Brisbane and Adelaide produced very similar results.

\section{The outer metropolitan cluster}

This was the largest cluster, with 43 electorates. Of these, 23 were held by Labor, eight of which were marginal. Ten of the 20 held by the Coalition were marginal. There was potential for considerable change, but despite that fact that there was a primary swing against Labor in every one of the 43 electorates except the Sydney electorates of Chifley (+0.7 increase), Fowler $(+7.9)$ and Greenway (+ 2.2 ), only four seats moved from Labor to the Coalition: Deakin and La Trobe in Melbourne, Lindsay in Sydney, and Petrie in Brisbane

Table 9: Patterns of party support, outer metropolitan cluster

\begin{tabular}{|l|r|r|r|r|r|r|r|}
\hline & \multicolumn{1}{|l|}{ NSW } & \multicolumn{1}{l|}{ Vic } & \multicolumn{1}{l|}{ Qld } & \multicolumn{1}{l|}{ WA } & \multicolumn{1}{l|}{ SA } & \multicolumn{1}{l|}{ Tas } & \multicolumn{1}{l|}{ Cluster } \\
\hline ALP primary & 37.30 & 39.90 & 34.40 & 30.70 & 41.90 & 39.90 & 36.80 \\
\hline ALP swing & -2.20 & -8.80 & -2.20 & -3.90 & -4.00 & -2.90 & -4.40 \\
\hline ALP two-party & 45.70 & 52.80 & 46.50 & 43.10 & 52.60 & 55.10 & 48.10 \\
\hline Coalition primary & 47.70 & 40.00 & 45.00 & 47.30 & 40.00 & 38.70 & 44.10 \\
\hline Green primary & 5.30 & 7.30 & 6.80 & 8.60 & 8.30 & 12.20 & 12.20 \\
\hline
\end{tabular}

Source: Australian Electoral Commission (2013).

In Sydney, the other five Labor-held seats were safe, and withstood a swing of -2.2 per cent. In Melbourne, the primary swing against Labor of -8.8 per cent was of landslide proportions, but Labor was saved by preferences from the continuing strong vote for the Greens in seats where it mattered. As mentioned, only Deakin and La Trobe were lost to the Liberal Party, both of which were marginal Labor before the election. In the Brisbane sub-cluster Labor held four seats and, with only a muted swing against Labor, was able to retain three, losing only Petrie. In Perth, Brand was saved when there was only a -0.4 per cent swing against Labor.

Perth produced the weakest result for Labor, with Adelaide recording the highest primary vote. In Sydney, Labor continued its hold on the western and south-western suburbs. There were significant differences in the Labor swing. Every Victorian outer metropolitan electorate swung against Labor, with the 
largest in Lalor (-18.8 per cent) following the retirement of Julia Gillard, Gorton (-12.1 per cent), McEwen (-10.2 per cent), and Scullin (-9.6 per cent). In Melbourne, the primary swing of -8.8 percent against Labor translated to -6.2 per cent on a two-party vote. As in the inner metropolitan cluster, the Green vote held up better in outer metropolitan Melbourne, and saved Labor seats.

Brisbane outer metropolitan electorates were better for Labor than the early polling in 2013 had suggested. Despite the predictions that Brisbane would produce a poor result for Labor, the 10 outer metropolitan electorates in Brisbane produced the lowest primary swing against Labor of the cluster. Despite that, Labor lost Petrie, and now holds only three of the 10 seats. In Sydney, Labor's fears were not realised: the western suburb electorates of Chifley, Fowler and Greenway actually showed a swing to Labor.

In Perth, swings were considerably more variable: -13.7 per cent against Labor in Canning, to only -0.4 per cent in the key Labor electorate of Brand, which Labor retained. In seats, it was a matter of status quo. A primary swing of plus 3.9 per cent was not enough for the Liberal Party to win Brand-Labor's only seat in the Perth cluster. In Adelaide, the election mirrored the polls with a swing of -4.0 per cent against Labor. Of the three electorates in the cluster, Boothby was strengthened for the Liberal Party, and Kingston and Makin became weaker for Labor.

The Green vote across the cluster declined from the 2010 level, in all cities, but was most noticeable in Melbourne. The Greens' best results were in Ryan (Brisbane, 14.4 per cent), Mackellar (Sydney, 14.2 per cent), Boothby (Adelaide, 12.0 per cent), and Pearce (Perth, 11.2 per cent).

\section{Explaining regional variability}

Examining the regional electoral geography, the 2013 election produced differential results, the highlights of which can be summarised.

New South Wales did not produce the overwhelming anti-Labor landslide that the early polls, and the very public traumas of the state Labor Party, had suggested. However, it was responsible for the loss of eight of the 17 seats that transferred from Labor to the Coalition. To a large extent, the 2013 election was won in New South Wales. Victoria produced a strong primary swing against Labor, but it won a majority of the two-party votes on the basis of Green preferences. Labor was apparently the 'least unpreferred' major party in Victoria. Despite that, Labor lost three seats: Corangamite, Deakin and La Trobe. 
Queensland, which had been forecast to be bad news for Labor under Gillard and was a key responsibility for the restored Kevin Rudd, produced only a small swing against Labor losing only Capricornia and Petrie. Western Australia had been predicted to show a strong swing against Labor, with the potential to deliver a complete wipe-out. But there was only a small swing against Labor, and no seats changed hands between the main adversaries (although the ALP did lose a Senate seat to the PUP in Western Australia after the April 2014 re-election).

In South Australia, the election result mirrored the predictions and the state political context: a strong swing against Labor, but the loss of only one seat. Tasmania was the weak state for Labor, with strong swings against Labor, and three of the five seats - Bass, Braddon and Lyons - moving to the Liberal Party. There was no change in the representation from the Australian Capital Territory and the Northern Territory.

The regional analysis was based on clusters of electorates with similar geographic and socio-economic characteristics. A summary of the results of the analysis suggests the efficacy of such an approach. The rural region has a distinct 'antiestablishment' political culture, and the 2013 election produced distinctive patterns of party support. Yet traditional patterns of support for the major parties were retained, although the precise location and context of the states in which they are situated did have some effect (especially with some strong local challenges from PUP and KAP). The major differences in voting patterns across the cluster occurred in the electorates which, while classified as rural, contained a significant and growing urban/industrial component. Examples are Hunter and Richmond in New South Wales, McEwen in Victoria, Blair in Queensland and Wakefield in South Australia. These had characteristics, and patterns of party choice, which more reflected the provincial city cluster than the rural.

The provincial city cluster also showed a strong similarity of patterns of voting, with the exception of the Queensland sub-cluster, all the electorates of which are formed around provincial cities embedded in rural areas, and which, after the Labor loss of Capricornia, is totally 'owned' by the Liberal National Party. In New South Wales, however, Labor retains five of the eight electorates, which is partly explained by the fact that the provincial cities contain elements of greater Sydney, rather than existing within rural areas. In Victoria, two provincial city electorates, Ballarat and Bendigo, have a strong rural influence whereas Corio is embedded in Geelong.

Overall, the metropolitan clusters showed a high degree of similarity in patterns of party support. There were occasional big differences recorded, which can be linked to the influence of a state political context: the high Green vote in Melbourne, the landslide against Labor in Tasmania, the differences between the 'ethnic' sub-clusters in Melbourne and Sydney, and the stable Labor 
primary vote in Queensland. A comparison of the patterns in the inner, outer, and total metropolitan clusters leaves a clear impression of similarities rather than differences in the primary votes and swings of both parties.

Our conclusion is that there was significantly more similarity, even greater uniformity, within the regional clusters in the 2013 election, despite the states in which they were situated, than within and between the states themselves. Place rather than party identification may be the main determinant of contemporary voting patterns. The 2016 election will provide further evidence about whether these prevailing patterns remain dominant.

\section{References}

Australian Electoral Commission (AEC). 2013. Election 2013-Virtual Tally Room. 4 November, viewed 3 February 2014: <results.aec.gov.au/17496/ Website/Default.htm>.

Economou, Nick. 2012. 'Victoria'. In Simms and Wanna (eds), Julia 2010: The caretaker election, Canberra: ANU E-Press.

McCall, Tony. 2012. 'Tasmania'. In Simms and Wanna (eds), Julia 2010: The caretaker election, Canberra: ANU E-Press.

Miragliotta, Narelle and Campbell, Sharman. 2012. 'Western Australia at the Polls: A case of resurgent regionalism', in Simms and Wanna (eds), Julia 2010: The caretaker election, Canberra: ANU E-Press.

Miragliotta, Narelle. 2013. 'The View from the West'. Paper presented at workshop, The Australian National University, Canberra, 2-3 November.

Simms, Marian and Wanna, John (eds). 2012. Julia 2010: The caretaker election. Canberra: ANU E-Press.

Thompson, Elaine and Robinson, Geoff. 2012. In Simms and Wanna (eds), Julia 2010: The caretaker election, Canberra: ANU E-Press.

Ward, Ian. 2012. 'Queensland'. In Simms and Wanna (eds), Julia 2010: The caretaker election, Canberra: ANU E-Press.

Wear, Rae. 2013. 'Queensland'. Paper presented at workshop, The Australian National University, Canberra, 2-3 November.

Woodward, Dennis and Curtin, Jennifer. 2012. 'Rural and Regional Australia: The ultimate winners?' In Simms and Wanna (eds), Julia 2010: The caretaker election, Canberra: ANU E-Press. 
This text taken from Abbott's Gambit: The 2013 Australian Federal Election, edited by Carol Johnson and John Wanna, published 2015 by ANU Press, The Australian National University, Canberra, Australia. 